\title{
Feminist Writing in Malayalam Literature- A Historical Perspective
}

\section{Saratchandran Nair}

\begin{abstract}
$\underline{\text { Abstract }}$
The paper deals with a historical account of "Feminism in Malayalam literature", a subject which has become highly relevant and was motivated to write after the aftermath of the "Nirbhaya case", which has caught the attention not only in India, but the world over and has become still more relevant in the present context. A review of the literary studies and translation studies are discussed in this paper. Particularly when we discuss about Kamala Surayya/Kamala Das/Madhavikkutty's works. In a limited paper like this, I had to bring in an overview of the situation of Feminism, the socio-cultural, historical accounts, apart from the literary aspects and also keeping the translation aspects to bear minimum.
\end{abstract}

\section{Introduction}

Feminist writing has to be seen as a classic case of a section of the society, which are deprived, oppressed and suppressed and suffering from gross inequalities. Any study of literatures of any language bring to the fore, the gross agonies that women have undergone over the ages or/are undergoing. Not a single day passes, without such atrocities committed on women unabatedly and unabashedly that humanity has to hang its head in shame. This article chronicles the happenings in Malayalam literature on this aspect and the development of Malayalam literature by critically analyzing certain prominent writers of Malayalam literature and 
their writings. It may not have covered all the writers, but certain prominent ones, who have changed the course of history and brought in awareness about the rights of women and immensely contributed to the development of the society.

\section{Historical and sociological background:}

It is told in the early part of the Christian era, i. e. the first Chera Empire, roughly estimated to be between $2^{\text {nd }}$ century B. C and $5^{\text {th }}$ century A. D, that women enjoyed equal rights as men and the contribution made by the great poetess of Sangam Classics, auvayyar, is remembered, whereas when one sees history, it is seen during the second Chera Empire, believed to be between $8^{\text {th }}$ century A. D and $11^{\text {th }}$ century A. D, the situation has changed dramatically and the hundred years of war between Cheras and Cholas, brought a lot of social and political upheaval that when men went out for war, women had to be left with the brother, who became the head of the family, the kaaranavar (the great Uncle) and the dictums of the uncle reined, where one could see the evolution of the marumakkattayam (matrilineal system). manusmriti was glorified during the second Chera Empire, which speaks volumes of the suppression of women. More than manusmriti, the Brahmins of Kerala adopted Saankarasmriti, which have put women of the Brahmin clan in a more backward position. According to Saankarasmriti, women of Namputiri 'illam' or 'mana' were forced to follow certain rules such as:

a. The women of Kerala Brahmin should not have thiirthasnaanaM

b. they should not have high education

c. they should not hear veedoochaaraNam (recitation of Vedas)

d. other than husband, they should not see any other men 
e. when they travel outside, they should have marakkuTa (an umbrella made of leaves of arecanut sheath) and should have a maid accompanying them.

f. they should not sing song and play

g. do not walk through streets during night times

h. during festive seasons, do not visit temples

i. do not wear dresses other than white coloured dress

j. do not have nose boring done

This clearly demonstrates the agonies of the womenfolk, against which the great writer, Smt. Lalithambika Antharjanam, herself a Brahmin woman, had written several stories depicting the agonies and sufferings they underwent and the shackles that they have to shed. One of the logics that the men folk brought forth in Kerala was 'the family property should not be divided'.

However, unlike other parts of India, women occupied an important position due to matrilineal system, as they were well protected (particularly the Nair women of Kerala as opposed to the Nampuutiri women known as Antharjanam, the eldest son of the Nampuutiri marries the Antharjanam and other brothers used to have only sambandam(visiting husband relation in Anthropological terms) and not allowed to marry Nampuutiri woman, these issues would be further elaborated in 'Lalithambika Antharjanam's writings'. It is also seen historically during $12^{\text {th }}, 13^{\text {th }}, 14^{\text {th }}$ century, after the downfall of the greatest and prosperous kingdom of South India, the second Chera empire, several small petty kingdoms took birth in Kerala and there have been often feuds between local chieftains and even women took up the study of martial arts, the famous kalari payattu, and the heroic valour of the famous Unniyarcha, the heroic damsel is well described in the folk songs of 'North Malabar', known as vatakkan pattukaL. It is also during this period that one could see women being portrayed as an object of sex 
in several literary works known as devadasi varnanas or erotic poems and also 'messenger poems' or sandeesa kavyas. So we have the famous sandesa kavyas known as unnuniili sandeesam, unnichiiruteevicharitam etc. in an amoral mixed poetic style. A new dawn arises in the form of devotional poems by Tunchattu Ramanujan Ezuthacchan, who wrote Ramayanam and Mahabharatam, in his classic kiLippaattu style. Of course his devotional songs had been preceded by poets like Cherusseri Namputri, who wrote Krishna Gatha. Lot of Socio political changes happened with the arrival of Portuguese in 1498 and thereafter. They were followed by the Dutch, the French and the English, who fought battles among themselves and or the locals for regaining supremacy, which culminated in the establishment of the East India Company by the English and the present state of Kerala, came to be ruled by three petty Kingdoms, Travancore, Kochi and Malabar. Travancore and Kochi were ruled by the respective kings and there were representatives called as residents of the British East India Company, whereas Malabar came under the rule of the Madras province. On $1^{\text {st }}$ Nov, 1956 the state of Kerala was formed, after independence and the states reorganization took place on the basis of linguistic principles. Prior to this certain important events would be worth mentioning. In 1859, one of the kings of Travancore declares that all children would have a right to education without bringing disparity between boys and girls and a girl's school would be started. Women's education was a turning point in the history of Kerala. Another epoch making event, happened on $26^{\text {th }}$ July, 1859, the first nationwide struggle for women liberation movement, got a feather in the cap, by the official declaration granting women belonging to lower caste, Nadar/Channar were not permitted to cover their breasts and enforcing that all would have a right to cover their bosoms. The victory of the Channar lahala or the upper cloth mutiny (maaru 
marakkal samaram), after half a century of struggle is widely seen as transformative movement that triggered a wave of renaissance movements that shaped modern Kerala. The introduction of English education by Lord Macauley was yet another event. The right for property division was yet another historic event, which transformed the Kerala society. Political events, such as the two world wars, the Russian revolution, the communist movement, the independence movements etc., had also rumblings in the Kerala society and had its undertones in the feminist writings. Colonisation and post colonization, Fukuyama's (1989) the end of the world theory, globalization, the need for protection of environment, development and sustainability, would be discussed in consonance with women's writing. Despite all these struggles and movements women continued to occupy a subaltern position, which is reflected in their writings and struggle of women to be on equal footing with men is still a dream. The analysis of their literary works is a pointer to this grim reality.

\section{Social transformations during the early part of the twentieth century.}

Several social transformations, which have happened in the early part of the twentieth century cannot be forgotten, when one thinks of the feminist movement in Kerala and many male writers and poets were also involved. These have brought in modernization. In a nut shell, if one can recall the movements, the following would have to be accounted for. These were days of processions and protests. It was the uprising of the oppressed classes, who were suppressed for several centuries by the landlords and feudal set up built up by the Brahmins and upper castes based on caste, class divisions. The domineering social movement led by Sri. Narayana Guru and the great poet Kumaran Asan, through his various 
illuminating poems, for upliftment of their community, the Ezhavas, was also an eye opener to other communities, who have been suffering for several centuries. Sri. Narayana Guru, not only preached for the emancipation of his community, but has given a call for equality of the entire humanity through his great words, "one caste, one religion and one god for all". He established a social organization by the name Sree Narayana Dharma Paripalana Trust in 1903. Another social reformer Sri. Ayyankali, established for the upliftment of dalits, the pulayamahajana, saadhu jana paripalana sabha in 1905. The Christians formed katholikka congress (1905), Nairs formed the keraliiya naayar samaajam(1907) and the Namputhiris formed namputiri yogaksheema sabha (1909). All these associations had created social transformations and for certain classes, it was the assertion for their rights. The khilafat movements took roots among the Muslims. Kumaran Asan, was a poet of par excellence that he saw women being oppressed, from not taking into account only the upper caste women, but from the point of view of the backward and downtrodden women, advocating for their education for better lives and emancipation. That was the reason he brought forth the view points as the centre stage in the poems such as chandaalabhikshuki and duravastha as quoted in Sarah Joseph (2000:272). Yet another great poet Sri. Ulloor Parameswara Iyer advocated for women's education in his poem vidyayute mahaatmyam, that by educating a girl, she not only brings light in her house but the house, she goes after marriage and also through her progenies to several houses.

Not only the movements by the downtrodden people, but there were Namputiri Brahmins such as V. T. Bhattatirippad, Premji M.R.B, E.M.S, the famous communist leader, who pioneered for the liberation of Nampuutiri women among the Nampuutiri youths. Among them were Nampuutiri women such as Parvati 
Nenminimangalam, Arya Pallam, Lalithambika Antharjanam, who took lead in ostracizing the old conventions that Namputiri women had to endure. The notable dramas regarding liberation of Namputiri women are atukkalayil ninnu arangatteeykku (1929) (From Kitchen to centre stage), tozilkeendrattileeykku (1948) (towards workplace). The former was an antidote for the domineering priestly caste, whereas the latter was for subjugating the male dominance. It also underlines the point that not only that woman comes to the forefront from the drudgeries of the kitchen to the outside world, but also take up a career for themselves and have to be economically independent.

Some of the other movements that have taken place and transformed the society to a larger extent are maaRu maRaykkal samaram (asserting the rights to cover breasts), ghosha bahishkaranam $^{1}$ by the Namputiri women, the communist movement, Temple entry movement(1924) etc. and all these have taken place in the late $19^{\text {th }}$ Century and the early part of $20^{\text {th }}$ Century. The Cochin king, Rama Verma (1895-1914), declared that 'all modernity can be kept outside the temple' and asserted that women come to the temple by covering their breasts. Sri. C. V. Kunjiraman's mother-in-law scolded her daughter-in-law for wearing upper garments, when she went out and said she need not dress like ummaacikaL(muslim women). Even another famous social worker of Kerala, Sri.Mannathu Padmanabhan caustically told the women folk of Kerala and remarked "is there a god sitting in the temple to see Nair women, without covering their breasts, then it is better that they boycott the temples, for protection of their dignity"(1931). It is the land where women had to pay taxes for covering their breasts and one woman, belonging to the then downtrodden community, who was staying in an European colony had to face the wrath of the Queen of Attingal, for having covered her breasts, that the queen ordered that her breasts be chopped off 
(Elankulam, Kunjan Pillai:1953). Such was the feudal set up in Kerala that women had to fight tougher battles to get their rights restored.

\section{Women writings in Kerala}

If one analyses the development of Malayalam literature, one could see the women writings in Malayalam have happened only towards the end of the $19^{\text {th }}$ century or early $20^{\text {th }}$ Century. The developments in the $20^{\text {th }}$ Century and the $21^{\text {st }}$ century have been phenomenal.

Ulloor S. Parameswara Iyer, the great poet and historian of Malayalam Literature accounts for 12 women writers of Malayalam from 1760 to 1947. During this phase women writers were confined to be satisfied with devotional songs, tiruvatira songs, kaikoTTikkaLi songs and historical themes, particularly the heavily sanskritised based ideas and forms. Consequent to the English education, an awareness was created among the common people about the literary developments of the west and this impact was felt in our regional languages and new genres were created coupled with Russian revolution. Towards the end of the $19^{\text {th }}$ Century and beginning of the $20^{\text {th }}$ century a flurry of the literary activities started. Different genres of literature generated. Social dramas emanated other than the usual historical and puranic dramas. Short stories, novels, journalism, travelogues etc. took birth. A new thinking took fold among the people for freedom and the clarion call given by Gandhiji made an impetus in the writings of several writers and poets such as Kumaran Asan, Vallathol Narayana Menon and Ulloor Parameswara Iyer, who extolled the virtues of educating girl child and strongly campaigned for emancipation of women. It is during this phase, the women writers and poetesses, such as Mary Jhon 
Thottam (1901-85), Kuttukulam Mary Jhon (1904-78), Kadatunattu Madhaviyamma (1909-2000), Balamaniyamma (1909-2004), Lalithambika Antharjanam (1909-1987), Ms.K.Saraswathiyamma (1909-1976) emerged. Balamaniyamma's poems are a true incarnation of mother's love and it's sensibilities, wheras Saraswathiyamma was a staunch feminist, whose writings have stirred the male dominated society and she had to endure several difficulties not only in writings but also in her personal life and she almost lead a lonely life, which is a poignant reminder of a mundane society. On the other hand Lalithambika Antharjanam, in her writings focused on the tyrannical attitude of the Namputiri men, which includes the suppression of women. She was also equally vociferous in stating that even poets saw "women as an object of charm, beauty, an instrument of 'bhogam' and never understood that they have hearts filled with agonies and sufferings".

In a recent $\mathrm{Ph} . \mathrm{D}$ thesis submitted to Calicut University, Sujathabhai (2009) analyses the lady characters of Lalithambika Antharjanam's stories and novel. As already stated her crusade was not only for liberating the Namputiri women folk from the yolks of suppression and oppression, but also, she utlilised her pen strongly for several liberal ideas. She was influenced by Tagore's literature, religious ideology of Swami Vivekananda and also the nationalist awakening of Mahatma Ganhiji. More than that her works were kindled by the liberation movement of Namputiri women lead by V. T. Bhattathiripad, M. R. B, Arya pallam and E. M. S. Namputhiripad. Fortunately for her, her parents had a liberal attitude and educated her. She was under the tutelage of N. S. Pandala (whom she calls as 'pandala sir', whom she considered as her 'guru'. But she could find around her, the agonies and suffering of young Namputiri women forced to marry very old men, who might have married this young woman as the fourth wife and might become a widow, which is 
reflected in the story muиTupaTam. She thought that if the Namputiri community has to progress, the only way was to bring out the Namputiri women out of their slumber and extricate them from the dark hallows of the Namputiri house known as the illam or mana. This was the staunch feeling of her elders and contemporaries like V. T. Bhattathiripad, M. R. B, Arya Pallam, E. M. S and several others of the yoga kshema sabha, who supported their social cause. But at the same time they had to face a stiff resistance from their very conservative community set up. All their literary contributions have been remarkable in different genres of Malayalam literature such as poems, dramas, short stories and novels. The most remarkable thing is that not only women like Arya Pallam and Lalithambika Antharjanam, but men like V. T. Bhattathirpad, E. M. $\mathrm{S}$ and M. R. B also fought for women's liberation and emancipation. V. T. was particular that all men and women needed equal education and freedom. V. T. realized that intercaste marriages or widow remarriages are necessities for a society and there was nothing taboo or sacrosanct about it. In the history of the Namputiri community, he initiated the conduct of marriage of his wife's sister nanneema with M. R. Bhattathiripad and in 1940's in V. T.'s house in the presence of other social reformers like Sri. K. Kelappan and Sri. M. C. Joseph, conducted the first inter caste marriage of his sister, Ittippapti and Sri. P. K. Raghava panicker and this was the first intercaste marriage in the Namputiri community. Reformation with in the Namputiri community and particularly that just being born as a woman, they had to endure a sinful and dreadful life and all these were reflected in the writing of writers such as V. T's rajaniirangam, poomvazi, (short stories) aTukkaLayilninnu arannatteeykku (drama) (from kitchen to the arena) etc., M. R. B's vaalkkannadi, Muuthiringode's puunkula are all collections, which are depictions of the agonies and suffering of the women of Namputiri community. 
maRakkuTaykkuLLile mahaanarakam (the real hell inside the maRakkuTa (an umbrella used by Namputiri women, when they go outside their homes), aphante makaL (the daughter of aphan (younger brother of the eldest Namputiri). These are remarkable creations, which represent the trials and tribulations of the Namputiri ladies and their children born outside their community through sambandam (Namputiri children born out of Nair woman or other subcastes cf: visiting husband relationship quite often referred in Cultural Anthropology), whereas Muthiringode's main themes were 'dowry issues' and smartha vicaaram ${ }^{2}$.

Around the 8 th cent. A. D., particularly during the second Chera Empire (825. A. D- 1090A. D.), the Brahmins became a dominant force in the socio-political set up of the Kerala society, temple became an important social institution and the Namputiri Brahmins were only allowed to enter the sanctum sanctorum of all the temples. They created a social situation and class/caste division, based on chatur varNyam, in which the inner most sanctum sanctorum, where the deity is situated is their prerogative and not other community was permitted to do puuja. The nearest communities such as Variar, Maraar, Chakiyaar etc., were treated as ambala vasis, who depended on the work done around the temple and the Nairs were permitted to visit the temple for worshipping and also were predominantly agriculturists, who used to contribute the produce for the welfare of the temple or were protectors of the temple. They were protectors of the Kings and other ruling class also. Some were given lands belonging to the Temple for cultivation and had rights over certain duties pertaining to the temple during temple procession. The other communities were totally barred from entering the temple and this situation prevailed until 1924, when Mahatma Gandhiji, with his followers entered forcibly the Vaikkom temple with all communities, known as the Temple entry movement. 
So the Brahmins believed that since they were performing the rituals based on the Vedic traditions and were the learned community, they were superior and nearer to God and also other communities should pay obeisance to them and made other communities to accept this dogma. The suudras, were relegated to the background. They had no say in matters relating to social, political or economic matters relating to the society and they sacrificed their lives for the welfare of the upper caste people. They had to suffer all indignities and the clear cut division on the basis of caste and class was prevalent. So, when the Brahmins became a dominant community, only the men folk of that community enjoyed all the previleges and the life of womenfolk was wretched and suffered all indignities. The Namputiri men became dominant, they made rules palatable to them and modified manusmriti and created saankara smriti. They created a society where men were the masters and the women were the slaves. They indoctrinated the famous lines of manusmriti in the following words:

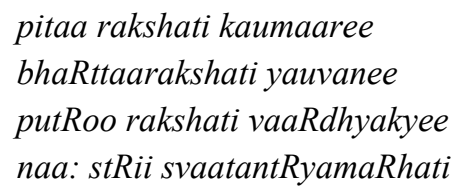

Apart from this, they also distorted the Dravidian culture, where women were given equal importance as men, which is reflected in the writings during the first Chera empire from $2^{\text {nd }}$ Cent. B. $\mathrm{C}$ to the $5^{\text {th }}$ Cent. A. D. The Namputiri men totally ignored the statements of protecting the women in the manusmriti by father, husband and son at the appropriate time and instead they were suppressed intellectually and morally and confined them to the inner quadrangles of the illam and kitchen and were made to believe in superstitions. Though, economically, the Namputiris were in a better position, their womenfolk lived a life of hell. They created certain 
institutions of marriage such as veeLi, adhiveedanam, pariveedanam, maaRRukalyaanam, etc ${ }^{3}$

In order that the property did not get further divided, they created a system in which the eldest Namputiri could only marry a Namputiri woman known as veeLi and other brothers had to marry women from other communities, which was known as sambandham, particularly the Nairs, who considered it as something prestigious. Thus Namputiris also had marital relationship with other Kshatriya communities, who were known as neetyaramma and the children born out of such wedlocks had no entry in their father's house and so most of the Nair ladies were confined to their ancestoral home known as taravaaTu and their responsibility was to bring up the children and please the bodily pleasures of the Namputiri husband, who would be visiting them occasionally. Please refer to the character Thankam in 'Agnisaakshi' in the novel of Lalithambika Antharjanam, which is portrayed so poignantly regarding the sufferings and social stigma endured by children of Namputiri's born out of marital relationship out of their community. It was at the time of her father's death that Thankam reached her home and could get a touch of her father, while he was gasping for the last breath. But because she touched at the time his soul was ebbing out of him and her father became polluted, the other Namputiris assembled there did certain purification functions and only after she and her mother were driven out of the house and did puNyaaham, did they do the remaining obsequies.. This clearly depicts the hard hearted traditions of the Namputiris and how it would inflict wounds on the two souls, the mother and the daughter and how women have been treated. Age was no bar in marriage. The eldest Namputiri could marry as many times as possible and their fourth or fifth wives would be young girls as old as ten or fifteen and the men used to be in their fifties or sixties or seventies. All Namputiri houses were not 
well-off and this created a situation in which young girls and older women could not extricate themselves and there were quite often saa patni rivalries and people were forced to marry off young girls due to dowry problems to older men. In order to avoid dowry, there was a system known as maaRRattinu kalyaaNam. Originally the brothers used to exchange and marry, but later it deteriorated to the state the fathers used the daughters in exchange. In order to marry off the daughter, a father would marry a young girl from the other side. The opinions of the girls were never considered, of course when a muussampuuri (the eldest Nampuutiri) brings another girl, he has to get the consent of the existing elder wife, but quite often, it was obtained under threat or coercion. Due to poverty or due to rivalry among wives of Namputiri, they endured all sufferings and their only function was to honestly carry out the duties of a wife or family woman, without grumbling, cursing her fate. In case, the parents were not able to get a proper alliance, they were forced to marry off to distant places such as Sirsi, Mangalore or Coimbatore and sometimes have ended up as prostitutes as depicted in the short story of V. T. Bhattathiripad entitled uttaram kiTTaatta coodyam. Even women with puritanical and conservative ideas were opposed to the sweeping changes that were taking place in the Namputiri community, which is reflected in the novel Agnisakshi, the central character Teeti, transforms into four stages and becomes a tapaswini, the wife of Unni Namputiri, who was always clinging on to old and puritanical ideas. Teeti was always under the tutelage of her brother Mr. P. K. P. Namputiri and got to know about the developments taking place around, from the letters written by him. Her channel of communication was through Thankam and the old people of the Nampuitri house had always frowned upon on these matters. She came from a more enlightened house, where women were permitted to read, though economically not to that extent of her 
husband. But she had to suffer all taunts and comments from the elders of her husband's house as stated by her in the following words "eеTTanu aareem sneehalyaannu toonnuпnuи okke peeTiyaa ...aphane.... amme.... aacarannaLe......... daivatteppoolum peeTiyaaNeeTTanu.. itinakattu kazhinnaal njaanum peeTiccu pRaantupiTiccu pookumennu toonnunnu. " (my husband is not having love to anybody, being afraid of everybody.. afraid of aphan, mother,.. traditions...even god, he is afraid of, if I live here, one day, I will also become mad). Unni, a staunch representative of the conservative set up also states that, in this house we cannot live according to our likings, we have to consider other's likes and dislikes, manampalli illam does not have these kinds of customs and traditions, here it is not our liking, which is very important but dharmam is pertinent and here bhoogam is not significant but family life is a tyaagam and life is a yajnam. From this we understand the central character teeti/deevaki/devaki behan and others are poles apart. She is a symbolism of womanhood, rights of women and fierce independence and representative of nationalism as always Lalithambika Antharjanam lived at a time of National awakening by Gandhiji and his ideals have been woven into her novel. When any woman goes out of the dictums of any community, always character assassination of a woman is the easiest weapon and similarly the Namputiri community has adopted a system known as smaartha vicaaram in order to control and subjugate women. So they adopted the same method, when Teeti walks out of the marriage and she became a leader advocating social change, the maanampalli illam was planning to impose smaartha vicaaram against her by outcasting her and ostracing her and they were planning to get Unni married for the second time, but the family people could not succeed and Unni had decided not to marry for the second time, which was a blow to their plans. When Teeti returns to her house, on hearing 
from somebody she wears modern blouse, the women folk of the house breaks open her trunk box and see whether she has blouses stitched, which clearly shows that they were opposed to the dramatic changes taking place in their society. It is sometimes seen that women are the enemies of women in the developmental process. The characters like eeTTante amma and the women folk of Teeti's house etc. etc are representative samples. It is also to be seen how bRaanticeRiyamma (the mad woman in 'Agnisaakshi'), literally becomes mad because the Namputiri (muttaphan) was always enamoured by an illegitimate relationship, he had with another woman varasyaar (a subcaste woman), who was very pretty to look at and every day when he will be visiting the varasyar, the lady will create a furore in front of her house and one day he thrashed her, despite that she used to create a havoc and slowly she turns to be a mad woman and in the words of the Neetiyaramma, the real agony of an antharjanam can be revealed and she poses the question, "who would not become mad, if she could not sleep at least one night with the man she wed"?. Of course there were also several Namputiris, who lived up to the ideals and lived a life of dignity and grandeaur and extensively contributed to knowledge. Lalithambika Antharjanam has penned several genre of literature such as poetry, short stories, autobiography, novel etc, but her forte had been undoubtedly short stories, which she herself mentions in her autobiography.

\section{Ms. K. Saraswathiyamma (1909-1976)}

It is necessary to understand and define what is exactly feminism or feminist writing. The best example would be to concentrate on the writings of Ms. K. Saraswathiyamma, who doggedly pursued and portrayed the strong feminine characters in her short stories and through her only novel 'premabhajanam'. It is 
stated in Chandrika (2000:30) that in reality Sarawathiyamma was a writer, who wrote for women and for their freedom. She was the one who added a chapter for the women writers of Kerala in Malayalam literature. It is the realization of any woman writer, who would be rereading with a feminist outlook. She has been considered as a turning point in Malayalam literature. Probably, it is the social situation, which prompted her to come to a realization on this aspect. At the age of seventeen, she lost her father and she had to face the world outside without the shadow of her father. It was at that time without the support of a male progeny, she had to face the outside world, a world of men, and she realized the limitations of a woman. Those days, it was a world of men. Men can do anything. Women can do nothing. It was a state, if only they could succumb to the dictums of men that women can live. Women have to stand in a low pedestal. In her own words she has stated "I was not ready to accept this fact, not only to oppose it, but was ready to attack it. "She had campaigned very strongly and she had sown seeds of women's liberalism far ahead for the women folk of Kerala and she came to be known as a "male antagonist". She was never a "male hater" but through her writings, she was treading a lonely path, which alienated her from others.

\section{T. P. Rajalakshmi (1930-1965)}

The prolific period of Rajalakshmi's writings can be considered as from 1945-1965 and was the torch bearer of the feminist movement, even before such a movement's different rays have taken roots in the Malayalam fiction world. Her lady characters could not be suppressed and confined to the inner chambers of a house and her characters have lived at their own will and wish and she had protested all forms of oppression and suppression. Before the thoughts of feminism had established as a thought process, she 
had given a clarion call about the indignities women underwent and all virtuous qualities have been personified through her characters. It is through her stories, such as makaL, oru adhyaapika jiivikkunnu, deevaalayattil, she narrates the severities and agonies and sufferings women underwent/undergo and how women long for love and protection. In the story ñaanenna bhaavam, the character 'Ammini' enters life out of her own will and with self dignity, which has been smudged and tarnished by the male chauvinistic view of men. The male protagonist, Krishnankutty, sees her as a personification of pride, arrogance etc. instead of her true nature of motherhood, affection, compassion, and above all, and a lady of fellow feeling. Here, Rajalakshmi proves that due to the arrogant male domination even personal relations within the family have been mutilated. Instead of the natural and expected healthy man and woman relationship with in a family, it appears a Lord and slave relation comes into force and Rajalakshmi establishes that men presumes to think that they have a superordinate relation and women, a subordinate relation instead of an equitable relation with in a family. In case, if a girl protests against this set up, she is almost treated as an outcaste.

Rajalaksmi's stories and novels have been objective, introspective and imaginative with staunch feminist underpinnings and her soul-searching agonies and the sufferings of her sister and other women folk around her have been truly narrated and depicted in her writings. It attracted lot of criticisms from some of her relatives stating that she is actually selling their stories and making money and she had discontinued writing for some time, but later she had commenced again, but she was a soul, who took on herself, which drew herself to committing suicide. She noted in her suicide note that she should put an end to her writings, so she would not be a botheration to others. Because, if she lives, she would continue to 
write and thus Malayalam lost one of the finest creative writers. In, 1956, through a long story makaL, she came to be established as a noted writer, which was published by 'Mathrubhumi'. In 1958, she penned oru vaziyum kuRe nizlukaLum which was followed by uccaveyilum iLam nilaavum (1960) and ňaanenna bhaavaM (1965). On 18-1-1965 she committed suicide. Recently, Sarala Bhai(2009) has elaborately studied in her $\mathrm{Ph}$. $\mathrm{D}$ thesis on the awareness of death and philosophy of life in the works of Rajalakshmi.

\section{Madhavikkutty/Kamala Das/Kamala Suraiya (1934-2009)}

Madhavikkutty, popularly known to Malayalam readers with this name and for her poems in English readers, she was known as Kamala Das and when she converted herself to a Muslim in 1999, she adopted the name Kamala Suraiya and she died as a Muslim. She was born on $31^{\text {st }}$ March, 1934 in Malabar in Kerala. She is the daughter of V. M. Nair and the famous Malayalam poetess, Smt. Balamaniyamma. Belonging to an illustrious family of Nalappat, well known for their literary contribution, she was married to $\mathrm{k}$. Madhava Das at the tender of age fifteen. She was well known for her poems in English, to Non-Malayalees as well a Malayalees. But she is well known in Kerala for her short stories and her autobiographical sketch, ente katha(1973) and later translated into English with the title "My story" by the writer herself in 1988, the epoch making and path breaking writer she was and stood for the values, she held until her death.. It got the attention of the world and was translated into 15 languages. Her poems, autobiographical sketches, short stories have all enriched Malayalam literature in content and form and exposition of several issues concerning women and no writer has had the courage of conviction to bring forth in depth the mind of women and their life with such intricate details. 
She was forthright in picturising female sexuality in relation with male sexuality or in isolation, even speaking for hermaphrodites, homosexuality, lesbianism in its naked form without any inhibition or hypocrisy. It appears that there was no writer before her or after her, who could pen such issues with great concern and so succinctly and at times poignantly. Her stories are also truly women centric and also account marital or extra marital relations and different facets of attraction or discontent or discordance of male-female relation and sometimes psychological that one can get several readings of her writings and really is enigmatic and unique in her representation as in the short story pakshiyuTe maNam (the smell of a bird).

In an interview given by Smt. Madhavikkutti to Sri. P. P. Ramachandran, when asked to comment on her concerns of feminism that can be read through her poems and stories and when it was remarked to her that her statements are critical of feminism. She told as follows:

"I'll tell you something. Feminism, as the westerners see it, is different from the feminism I sense within myself. Western feminism is an anti-male stance, I can never hate the male because, I have loved my husband and I still love my children, my sons. And I think from masculine company, I have derived a lot of happiness. So I will never be able to hate them. Most of the feminists, I met outside the country were lesbians-out and out lesbians. I do not think, I am a lesbian. I tried to find out. I experiment with everything. I tried to find out, if I were lesbian, if I could respond to a woman. I failed, I must speak the truth. I believe that we must abandon a thing, if it has no moral foundation, whether it is belief, a political system or a religious system" (Indian literature, 1993:145-161, as quoted in Latha.T.R,283). The views of Madhavikkutty on feminism are clearly outlined in the above words and one may read her story 
chandana marangaL, along with this statement, whether it was an experiment.

Recently in a book entitled madhavikkuttiyuTe kathakaL (Madhavikkutty's stories- a feminist reading)- a study by Mini Prasad(2011), reveals an inner-depth of more than fifty stories of hers and each story has been analyzed by the women from various professions and each story has been analysed in their own perspective and the general editor was very particular that only women should evaluate which gave real credence to the real substance and Malayalam literature has been enriched by this account. But the moot question arises as to why Kerala society is crippled with so many cases of torture and torment of women and even small babies are not spared, see the infamous "suuryanelli rape case" and several others. A society with such high rate of literacy and all the social indices are high in comparison with other states, how could such unholy incidents happen. These issues are much reflected in the stories of Smt. Sarah Joseph (another feminist writer of repute, discussed below) that in the novel aalahayuTe peN makkaL, how the red lips of a baby is also a titillating feast for an elderly man with lust".

In several of Madhavikkutty's stories, it is noticed that there are intricacies and brown areas, which men can never digest and it is true as Mini Prasad(ibid) has succinctly put it, there are several areas, which could be treated as feminine views, feminine looks, feminine reading. Let us examine one story for exemplification. Though the theme is subtle, but it has deep ramification as Madhavikkutty sees it. The views of Prema Jayakumar (ibid:79) are extremely pertinent that many of Madhavikkutty's stories are feminist. It is not that they are antagonistic to men, that it is part of humanism and uphold humanity to its highest order. Among human 
beings, one could not see the half side of humanity. They become intolerant to the views of the women folk that Madhavikkutty gets highly perturbed on the plight of women. In the story kaaliccanta (Cattle market), a representative sample of two women, a grandmother and granddaughter meeting a stranger, a young man, with looks and features enters the house and informs that he is in search of a good 'cow', for purchasing. The grand mother tried to convince the young man, the virtuous qualities of her young Granddaughter, thinking the man is a bachelor and he is also interested to marry, though he has come to purchase cattle. On surveying the situation, he was not impressed and at the end of the story, informs them that he is already married and has children. But the young woman was disturbed by his looks and enquiries regarding the cow, whether it has sufficient number of teeth and whether its tail is sufficiently long. Madhavikkutty uses this dvantvaartha pRayoogam. Through this story, she brings to the fore, the agonies of parents and girls to find a proper match and the mental agonies the girls have to surmount, when it comes to the question of marriage. Quite often the parents and elders of a family in an Indian set up are a worried lot that their girl child is not in a position to get married to a suitable person of her choice or wish, but have to succumb to the pressures of the parents or to their dislike. Here the independence of the girl is put to acid test and quite often ends in marriages not true to expectations of the girl. Indirectly the young man is at liberty to choose from a variety of choices, as if in a cattle market, which are displayed in front of him. Truly in this story, the young man was not married and he bluffs to the ladies that he was married. He was in search of a young woman true to his dispensation, but he could not find. It underlines the point that very often, men who are in search of a bride, actually goes out with such carefree attitude, as if going to a cattle market and the helplessness 
of a young girl, agonizingly waiting to get married and most cruel, if her looks are not up to the mark, for no fault of hers, she has to suffer the ignominy and nobody bothers about the look of a man, his education or his other virtues. Even if, it is of low levels, they are not serious issues worth considering. So, Madhavikkutty analyses such issues in various angles. For her concerns of feminism are such issues.

\section{Smt. Sarah Joseph (1946)}

In the context of a subjective analysis of post-modernism, it can be said to a certain extent that the matters dealing with Feminism, form one of the important matter and the crux of the issues related to it, as quoted by Maya (2005:35), referring to one of the great poets of Malayalam Literature, Sachidanandan's study of, PapattaRa, 1990, a short story by Sarah Joseph. Further Maya (ibid) states as quoted by Sachidanandan that from a historical perspective of classifying short stories in Malayalam literature, Sarah Joseph's stories, could be categorized, based on the structure of the story, content and language, she has traversed a new path. As time passed, the content exposed the tresses of women, breasts, thighs, delivery of a baby and compassion of mother hood, reaching the zenith of sexuality in its naked form and the contemporaneous issues concerning women. At times she traversed on paths not tread by other women writers and which was unpalatable to a majority of people, who have never heard or familiar with such issues and made literature as a means to achieve and a weapon, which was used effectively. Those sections of society, which were critical of it, were only the dominant males, who were satisfied with appreciation of the elite class and not bothered of the stark reality and social concerns and they stated that these are only mere slogans of the female elk. But Sarah Joseph, through her novels, like aalahayuTe peNmakkal, 
maaRRatti, oTappu, aati and several other short stories of prime importance like paapattaRa, nilaavaRiyunnu, kanyakayuTe pullingam, kooNiyum reviyum etc, and several other stories, could through her unstinted efforts, topple the domineering male clan in the Malayalam literature. Through her female characters, she was able to paint a new picture, which Kerala women were unfamiliar.

\section{The new generation writers on feminism:}

In a vast literature and in a brief paper of this sort, it is very difficult to write on all writers and so I have highlighted only the most significant of them. This may have limitations, which would be taken up later.

There are several others, who deal with feminism from a modern perspective such as Gracy, Ashita, Gita Hiranyan, Chandramati etc. of which Sitara. S and Indu Menon stand out.

Maya (ibid) concludes in her article, if women writers sincerely make efforts in bringing out the female characters, the issues on sexuality could be dealt with properly. But, of course, while dealing with such issues, it has to be dealt with a proper sense of responsibility and the need is to muster courage in executing it.

Another genre of literature is poetic renditions on feminism and as a representative sample, I would like to discuss the poem by Vijayalakshmi, "mRugaSikshakan"(1991).

The poem is in Malayalam script as I do not feel like transcribing in any other language, as the feel of the poem would be lost. 


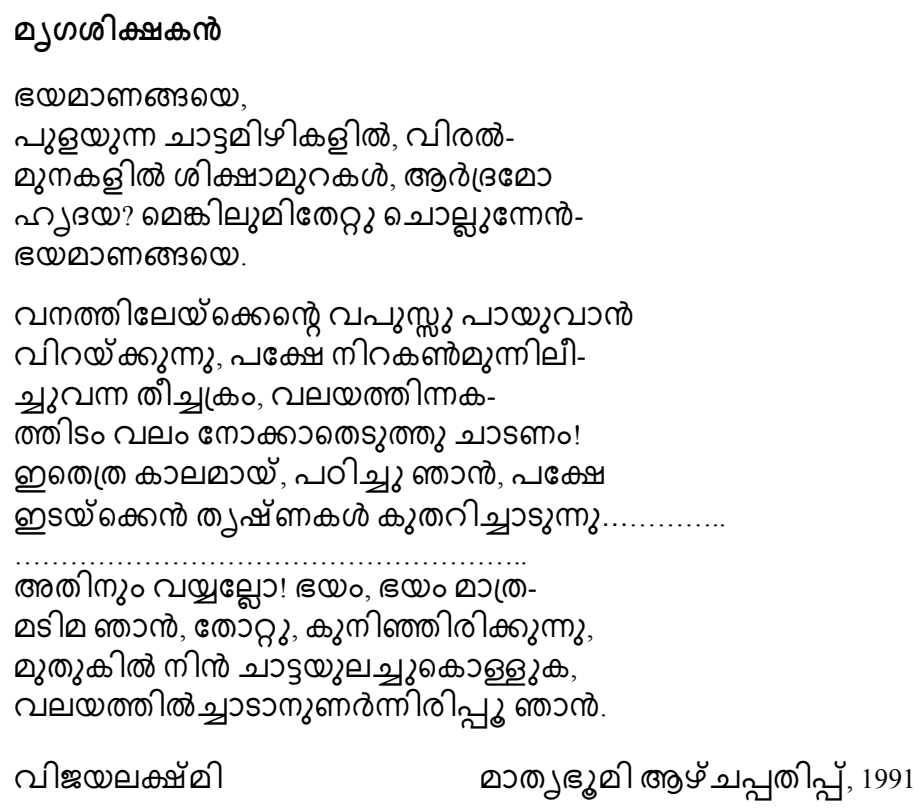

\section{Mrigasikshakan}

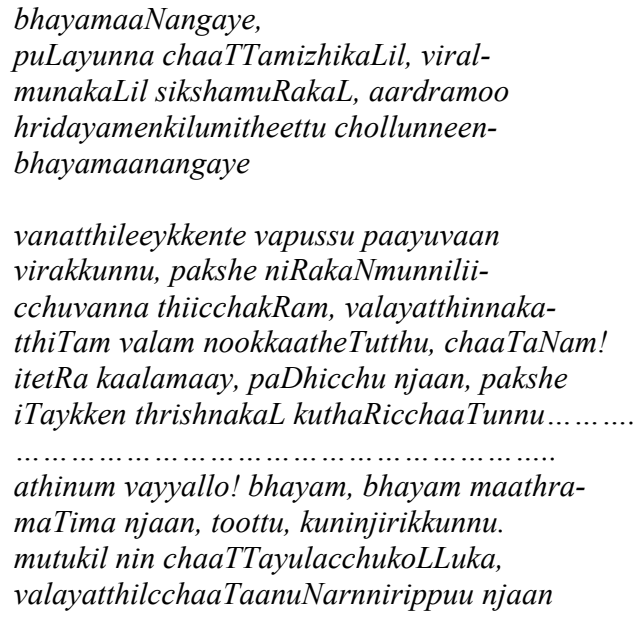

VijayaLakshmi 
Tradition is one which cannot be devoid of literature. In Vijayalakshmi's poem "mRugaSikshakan", when tradition becomes an inseparable entity, ideas and experiences have been brought with a unique perception and reflected in this poem.

The poem deals with the dual entities mRugam (animal) and Sikshakan (trainer) and has different connotations in different contexts. In an explicit denotation "the mRugam" is obeying the "sikshakan", even though in the mind, it has an implicit desire to protest, due to the overpowering and domineering personality of the sikshakan, it surrenders to it meekly and helplessly and having had to jump into the net, is the meekness of the animal, and its pathetic end.

The animal and the master are two contradictory dvandams. In the poem, the individual - society, the oppressor - oppressed, man - woman etc form the opposing imageries and all of these have to be read together to understand the cascading effect the poem mRugaSikshakan gives.

In the above said opposing imageries, it is rare to observe a non-volatile state in the present day society. Even though there is an innate desire to reject the traditions and customs, rules and regulations, which have been followed for centuries in an individual, the individual succumbs to the pressures of the society and meekly surrenders. See the lines idaykku en tRushnakaL kutaRiccaTunnu just like an animal, the individual mind is jumping for protest but doesn't do it, due to the fear of society. In the imagery of Woman Man, in a normal traditional family set up, the woman is expected to live in an amicable way, may be by sacrificing all her individual potentialities, whereas a "man" can explore any activities according to his whims and fancies and nobody questions it. Even though 
tradition bound society has been philosophizing that the woman should be confined to home, the woman is urging to become liberal, finding her confidence and her natural potentialities, trying to liberate from the yolks of suppression and oppression of man and getting an innate urge to liberate herself from man's net. But all her urges to become liberal becomes insignificant in front of the muscle power of man and succumbs to the net of the man mechanically as fate has dictated and submission and surrender is her only choice.

The oppressed is standing in front of the oppressor, witnessing of all his atrocities and torments, without challenging, even though at times, her animal instincts of the cave dweller arises, in front of the oppressor, she is forced to submit to the dictums helplessly. See the lines

kuniyunnu kaNNukaL avante nooTTattil (the eyes are drooping from his looks)

taLarunnu deeham avante haasattil (the body is trembling/weakening on his demonic laughter)

The sikshakan is standing with a whip in front of the mRugaM, to make it jump in to the net, but it's mind is thinking of the forest, it's pair, it's children, of the rocks and the cluster of bamboos and it's beautiful figure appearing in the clear water flowing down below, on a moony night, its urge to jump out of the net, but the word "fear", torments its mind and finally it succumbs and surrenders to the dictums of the oppressor. Several meanings could be read out of the poem and the dual imageries of mRugam and sikshakan, a reflection of the marginalized subaltern sections of society, of which woman forms one. 
In the post-modern literature, feminism forms one of the issues and may be the pertinent issue in a globalised world and other issues such as protection of environment, deforestation; dalit issues etc are equally significant. Feminism in a globalised world is equally the concern of the younger generation of women writers. As a consequence of globalization, family structure is getting transformed; the work culture and work ethics are all getting transformed to a large extent. In this context, morality as a serious issue is cropping up. Among the feminist oriented writers, Sitara. S, K. R. Meera, Priya. A. S, thinks how "human body", a post modern concept, becomes a commodity in art. There are no concealment of sex and open writings on homosexuality, lesbianism in their stories. The moot question is whether literature, per se, has also become a commodity, as literature can be written according to the needs of the society.

\section{Conclusion}

In conclusion, one could say that Malayalam literature has made an impact in the lives of women in Kerala to a larger extent, but lot needs to be done due to the double pronged approach of the Malayalees. Though one professes for anti dowry system, but the maximum dowry is given and taken in Kerala and the proliferation of the jewellery shops and the demand for gold have been highest in Kerala. Though we dream of casteless, religionless, egalitarian society, the reality is on the contrary and the moot question is where are we heading for? The incidence of atrocities against women and girl children are on the rise. How safe are our women and children? Kerala, inspite of being highest literate state, how all these atrocities are happening? 
In the Mathrubhumi Sunday supplement (23 ${ }^{\text {rd }}$ Dec, 2012), the questions asked by Sarah Joseph, while narrating about the drama tozilkeendrattileeykku, which was cast and appearing as a docu film and played on $23^{\text {rd }}$ Dec, 2012 at Thrissur, though the antharjanams (Namputiri women) have questioned the male dominance and narrow strictures imposed by the Brahminical class and have started to work and live on an equal footing in all walks of life, but in reality, internally are they on an equal footing and fully liberated? In truth, in reality, it is a clear NO, after a lapse of 64 years after first enactment of this drama.

\section{Notes:}

1. "ghoosha bahishkaraNam". ghoosha is an upper garment, a piece of cloth worn by women of Namputiri women(antharjanam) without covering their breasts with a blouse, but covers with a 'ghoosha' and then go out with an umberalla known as 'maRakkuTa'(made of palm leaves). They have decided to boycott this custom and started wearing blouse, which was considered as affront to their community.

2. "smaaRtha vicaaraM": In case, if chastity of a Namputiri women is suspected, then they are ostracized and publically, she would be cross examined. In "saankara smriti", in chapter 8 details are provided in 36 slokas, how it has to be conducted.

3. These terms refer to the marriage systems followed by the Namputiri. The eldest son of a Namputiri could only marry an 'antharjanaM' and it is known by the term'veeLi' and all other sons can have 'sambandhaM', with other communities such as ambalavasis and Nairs. (visiting husband relationship, known in Anthropology). These systems would have prevailed so that family property would have to be protected and before "aaLoohari division", came into existence." "adhiveedanam" is when a legally wedded wife is alive, marrying another lady. "maaRRattinu kalyaaNaM", is if a sister has to be married off, marriage by the brother to the sister of the would be husband. 
(exchange marriage). In certain situations, it went to the extent of Fathers taking advantage of the situation, in order to marry off one's daughter marry a young girl from the opposite side, particularly from far off places such as Sirsi, kundapur, Mangalore, Coimbatore etc., which has resulted in prostitution. The girl, being illiterate and being far from home have been driven to become a prostitute. "pariveedanaM" is when the elder brother does not get married and when younger brother marries(ref. Sreedevi, k. p, 1999 for further details)

\section{REFERENCES}

Chandrika, C. S. 2000. “K. Saraswatiyamma”:Sahitya Acdemy; New Delhi.

Elankulam, Kunjan pillai : "keeraLa caritRattile iruLatanna eedukaL".

Latha, T. R. 2009. A change of Tongues :Ente Katha vs My story, Unpublished Ph. D Thesis, University of Kerala.

Maya. S. 2005. KeeraLa stRiikaL, tan bhaava sudhi in Madhyamam p. 3235 Sarah, Joseph(2000):' Kanniirum Kinavum-Vimocanavum, in Nammute Saahityam, Nammute Samuuhamvol. 2, 1901-2000, ED. M. N. Vijayan:Kerla Sahitya Academy, Thrissur.

Sarala Bhai. 2009. "The awareness of the Death and the philosophy of life in the works of Rajalakshmi”, Unpublished Ph. D thesis, Calicut University.

Sreedevi, K. P. 1999. "keeraLattile nampuutir stRiikaLuTe gatakaala caritRavuM vaRttamaanavasthayuM" in anjuuRu vaR\$atte keeraLaM, cila aRivadayaaLangaL, Current Books, kottayam. pp. 295-307

Sujatha Bhai, G. 2009. "Lalithaambika antaRjanattinte stRii kathaa paatRangaL -oru pathanam (women characters in Lalithamika Antharjanam's works a study), Unpublished Ph.D thesis, Calicut University.

Acknowledgement: I am particularly thankful to Maharashtra Sahitya Academy, Pune and it's honorable members for kindling my interest in literature and in particular Malayalam Literature, though basically, I am a Linguist. My heartfelt thanks also go to Mrs. Ashwini Dhongde, who has been persistently requesting for this article. Mistakes, if any are solely 
mine. The Marathi version of the article has been published in a Collection of articles on Feminism by The Maharashtra Sahitya Academy, PUNE entitled" Striivadi bharatiiya bhaashatil striivaadi sahitya Maharashtra Sahitya Parishad, Pune, First edition, January 2016. 